\section{Alnylam's RNAa play}

\section{By Lev Osherovich, Senior Writer}

A study in Nature Structural \& Molecular Biology proposes a mechanism for small RNA-induced gene activation, a process that results in upregulation of poorly expressed genes. ${ }^{1}$ Although the jury is still out on what the precise mechanism is, Alnylam Pharmaceuticals Inc. has wasted no time in exclusively licensing the relevant IP from three universities. The technology could mark Alnylam's foray into disease areas typically occupied by gene therapy companies and transcription factor-targeting companies.

RNA-induced gene activation (RNAa) is a small interfering RNAbased process in which gene expression is modulated by targeting cryptic transcripts in the promoters of genes, thus providing a tool for potentially upregulating poorly expressed genes that are at the root of some diseases.

The NSMB study was conducted by a team from the laboratories of David Corey, professor of pharmacology, and Bethany Janowski, assistant professor of pharmacology, at the University of Texas Southwestern Medical Center (UT Southwestern). The study was coauthored by Brett Monia, VP of antisense drug discovery at Isis Pharmaceuticals Inc., which makes antisense therapeutics.

Alnylam and Isis are partners in Regulus Therapeutics LLC, a joint venture that develops microRNA therapeutics. The core focus of Alnylam has been RNA interference.

In contrast to the well-characterized RNAi process, which lowers gene expression by targeting transcripts for destruction, RNAa increases transcription and thus raises protein levels. RNAa is triggered by the same type of double-stranded RNA precursors found in RNAi, but it targets noncoding promoter regions rather than open reading frames.

"We normally associate RNAi with reduction in gene expression," Corey told SciBX. The ability to upregulate gene expression using RNAa "puts up a whole new set of genes as targets."

RNAa could be used to treat hereditary disorders involving partial loss of protein function due to mutations or lowered expression. These include sickle cell disease (SCD), certain forms of cystic fibrosis (CF) and several common cancers.

\section{Mechanism breakthrough}

The current study originates from the authors' earlier work describing the effect of dsRNA targeting the promoter of the progesterone receptor gene. According to theory, this treatment should have had no effect on gene expression. Instead, the researchers actually saw higher expression of progesterone receptor mRNA and protein. ${ }^{2}$
"Most people associate RNAi with recognition of mRNA," said Corey. "We found that you could target sequences using dsRNA that were not homologous to mRNA."

The processing of dsRNA into siRNA molecules that target the destruction of mRNA is well understood. ${ }^{3}$ However, the conventional RNAi model does not explain how dsRNA specific for a nontranscribed promoter region could increase gene expression.

Indeed, Corey and Janowski found that the promoter region is not transcriptionally silent, but instead it is the source of previously unsuspected transcripts. Sequencing these transcripts revealed that they ran in the opposite direction - that is, they were antisense to-the downstream coding region.

The team focused on a pair of highly expressed promoter-derived antisense transcripts. Using a transcript-silencing technique developed by Isis, the researchers selectively destroyed the transcripts and found that RNAa directed toward the corresponding sequence no longer worked.

Corey and Janowski's team then showed that RNAa molecules directly interacted with promoter-derived antisense transcripts and formed a complex with chromatin-associated proteins and Argonaute (AGO), a protein component of the conventional RNAi pathway that ordinarily turns dsRNA into siRNA.

Here, however, researchers found that the AGO-RNAa complex is stable and, unlike RNAi, does not undergo further processing that leads to destruction of the target transcript.

"We've seen no evidence that the antisense transcript is cleaved," Corey told SciBX.

These findings ruled out one model for how RNAa molecules might work - they do not degrade the promoter-derived antisense transcripts as in RNAi.

Instead, Corey thinks the promoter transcripts form the core of a protein-RNAa complex that does not inhibit transcription, but rather recruits transcriptional activators, thus boosting expression of the downstream gene.

Corey told SciBX that the natural mechanism behind the RNAa effect may resemble that of miRNAs, which are naturally occurring molecules that regulate the transcription of numerous genes in response to stress.

\section{Chromosomal regulation}

The UT Southwestern team is one of three academic laboratories that have licensed their RNAa discoveries to Alnylam. The company has also acquired licenses for RNAa work from the laboratories of LongChen Li, assistant professor of urology at the University of California, San Francisco (UCSF), and Fred Gage, professor of biology at the Salk Institute for Biological Studies.

When RNAa was first described by the Gage lab, "it was a very interesting observation that really puzzled people," said Alnylam CEO John Maraganore. Despite demonstrations of the reproducibility and wider relevance of RNAa by Li's team, the mechanism remained murky for years, Maraganore noted. ${ }^{4}$ 
Table 1. Turning on genes. Selected companies with products in the clinic that lead to expression of a particular gene.

\begin{tabular}{|c|c|c|}
\hline Company & Technology & Lead gene-based product [status] \\
\hline $\begin{array}{l}\text { Amsterdam Molecular } \\
\text { Therapeutics } \\
\text { (Euronext:AMT) }\end{array}$ & $\begin{array}{l}\text { Adeno-associated virus } \\
\text { (AAV) vector technology }\end{array}$ & $\begin{array}{l}\text { Glybera (AMT-011) AAV vector encoding lipoprotein lipase (LPL) to treat LPL deficiency } \\
\text { [Phase III; submit Marketing Authorization Application (MAA) 4Q08] }\end{array}$ \\
\hline $\begin{array}{l}\text { AnGes MG Inc. } \\
\text { (Tokyo:4563) }\end{array}$ & $\begin{array}{l}\text { Plasmid DNA vector } \\
\text { technology; hemagglutinating } \\
\text { virus of Japan (HVJ) vector } \\
\text { technology }\end{array}$ & $\begin{array}{l}\text { Collategene plasmid DNA encoding hepatocyte growth factor (HGF) to treat critical } \\
\text { limb ischemia in arteriosclerosis obliterans and Burger's disease [under review in Japan]; } \\
\text { Collategene is partnered with Daiichi Sankyo Co. Ltd. (Tokyo:4568; Osaka:4568) and uses } \\
\text { DNA plasmid technology from Vical Inc. (NASDAQ:VICL) }\end{array}$ \\
\hline $\begin{array}{l}\text { Applied Genetic } \\
\text { Technologies Corp. }\end{array}$ & AAV vector technology & AAV vector encoding the $\alpha 1$ antitrypsin (AAT) gene to treat AAT deficiency [Phase I] \\
\hline $\begin{array}{l}\text { Ark Therapeutics Group plc } \\
\text { (LSE:AKT) }\end{array}$ & $\begin{array}{l}\text { Adenovirus vector } \\
\text { technology }\end{array}$ & $\begin{array}{l}\text { Cerepro adenovirus vector encoding herpes simplex virus thymidine kinase (HSV-tk) followed } \\
\text { by ganciclovir therapy to treat operable malignant glioma [Phase III; resubmit MAA 4Q08] }\end{array}$ \\
\hline Ceregene Inc. & AAV vector technology & $\begin{array}{l}\text { CERE-120 AAV Type } 2 \text { vector encoding neurturin (NTN) gene to treat Parkinson's disease } \\
\text { [Phase II]; CERE-120 is partnered with Genzyme Corp. (NASDAQ:GENZ) }\end{array}$ \\
\hline $\begin{array}{l}\text { Introgen Therapeutics Inc. } \\
\text { (NASDAQ:INGN) }\end{array}$ & $\begin{array}{l}\text { Adenovirus vector } \\
\text { technology }\end{array}$ & $\begin{array}{l}\text { Advexin adenovirus p53 tumor suppressor gene therapy to treat recurrent, refractory } \\
\text { squamous cell head and neck cancer [under review in U.S./EU] }\end{array}$ \\
\hline $\begin{array}{l}\text { Mirus Bio Corp., being } \\
\text { acquired by Roche } \\
\text { (SWX:ROG) }\end{array}$ & $\begin{array}{l}\text { Plasmid DNA vector } \\
\text { technology; Pathway IV } \\
\text { gene-delivery procedure }\end{array}$ & $\begin{array}{l}\text { MyoDys plasmid DNA encoding the full-length human dystrophin gene to treat Duchenne } \\
\text { and Becker's muscular dystrophy [Phase I]; partnered with Transgene S.A. (Euronext:TNG) }\end{array}$ \\
\hline $\begin{array}{l}\text { Neurologix Inc. } \\
\text { (OTCBB:NRGX) }\end{array}$ & AAV vector technology & $\begin{array}{l}\text { AAV vector encoding the glutamic acid decarboxylyase (GAD) gene to treat Parkinson's disease } \\
\text { [Phase I complete] }\end{array}$ \\
\hline $\begin{array}{l}\text { Oxford BioMedica plc } \\
\text { (LSE:OXB) }\end{array}$ & $\begin{array}{l}\text { LentiVector gene-delivery } \\
\text { technology based on } \\
\text { lentiviruses; retrovirus vector } \\
\text { technology }\end{array}$ & $\begin{array}{l}\text { ProSavin LentiVector carrying three genes encoding enzymes for dopamine synthesis to } \\
\text { treat Parkinson's disease [Phase I/II]; MetXia engineered retrovirus vector encoding CYP2B6 } \\
\text { cytochrome p } 450 \text { liver enzyme that converts cyclophosphamide into an active form to treat } \\
\text { pancreatic cancer [Phase II] }\end{array}$ \\
\hline $\begin{array}{l}\text { Sangamo BioSciences Inc. } \\
\text { (NASDAQ:SGMO) }\end{array}$ & $\begin{array}{l}\text { Zinc finger DNA-binding } \\
\text { protein (ZFP) transcription } \\
\text { factor technology }\end{array}$ & $\begin{array}{l}\text { SB-509 plasmid DNA encoding a ZFP transcription factor to upregulate VEGFA gene } \\
\text { expression to treat diabetic neuropathy [Phase II] }\end{array}$ \\
\hline $\begin{array}{l}\text { Targeted Genetics Corp. } \\
\text { (NASDAQ:TGEN) }\end{array}$ & AAV vector technology & $\begin{array}{l}\text { tgAAC94 AAV encoding tumor necrosis factor (TNF) receptor linked to the } \mathrm{Fc} \text { region of } \\
\text { immunoglobulin (TNFr:Fc) to treat inflammatory arthritis [Phase I/II] }\end{array}$ \\
\hline Vical & $\begin{array}{l}\text { Plasmid DNA vector } \\
\text { technology }\end{array}$ & $\begin{array}{l}\text { Allovectin-7 plasmid-lipid complex containing the DNA sequences encoding HLA-B7 and } \\
\beta_{2} \text {-microglobulin to treat metastatic melanoma [Phase III]; partnered with AnGes MG }\end{array}$ \\
\hline
\end{tabular}

Now, said Maraganore, Corey and Janowski's paper "clearly indicates that there are biological processes that are likely to be relevant to dsRNA and miRNAs that can regulate expression of genes at the chromosomal level," rather than post-transcriptionally like RNAi.

However, not all researchers accept the NSMB study as the best explanation for how RNAa works.

Li said the Corey-Janowski study was a "critical first step" toward understanding the mechanism. However, he told SciBX that his lab's data about how RNAa works at the promoter of cyclin-dependent kinase inhibitor 1 (CDKN1A; p21; CIP), "does not support their conclusions" about the mechanism.

Li would not discuss his proposed alternative mechanism, but he said the model will be presented in a forthcoming publication.

\section{Transcription to translation}

Mechanisms aside, Li and Corey agreed that the key challenge to applying the method for therapeutics will be to work out how to design good RNAa constructs. Currently, finding promoter sequences that work as RNAa inducers is hit or miss. Li noted that his lab is formulating rules to define which promoter sequences work best.

Moreover, not all genes make good RNAa targets. Only genes undergoing active transcription can be further stimulated through RNAa, rul- ing out genes silenced by methylation or chromosomal inaccessibility.

"For RNAa to work, the chromatin needs to be poised for transcription," said Li.

In testing numerous RNAa sequences and target promoters, the UCSF and UT Southwestern groups have further found that certain RNAa constructs can have the opposite effect of typical RNAa molecules, actually inhibiting transcription. Such constructs may find a use in situations where RNAi doesn't work.

Corey told SciBX that the therapeutic challenge for both RNAa and RNAi is to deliver the dsRNA precursor molecules to the appropriate cell types. He suggested the liver could be the first place to focus because of previous successes in dsRNA delivery to that organ.

\section{The deal}

This licensing deal puts Alnylam into a space traditionally occupied by gene therapy companies and biotechs such as Sangamo BioSciences Inc. that are developing alternative gene activation technologies (see Table 1, “Turning on genes”).

"With RNAa technology, you can leverage the host machinery to turn up native genes," said Bruce Booth, a partner at Atlas Venture. "It's fair to say that this is a play into the gene therapy space." Booth is a cofounder of miRNA company miRagen Therapeutics Inc. and was an early investor in Alnylam. 
"Activation of endogenous gene expression is a potentially game-changing therapeutic modality," said Philip Gregory, VP of research at Sangamo.

Sangamo uses engineered zinc finger proteins to increase gene expression to treat a diverse range of indications. The company's lead compound is SB-509, a plasmid encoding a transcription factor that increases expression of VEGFA. It is in Phase II testing for diabetic neuropathy.

Although the Corey study provides mechanistic understanding for the "unexpected finding of gene activation" by dsRNA, Gregory told SciBX that questions about the generality of the mechanism and its therapeutic usefulness remain unanswered.

Booth, who noted Atlas no longer holds a position in Alnylam, agreed that "it's too early to tell how this technology landscape will play out in the clinic."

Nevertheless, he said, "it's an early landgrab over what could be prophetic IP in the RNAa space."

Maraganore cited several "areas of interest" that Alnylam is exploring for RNAa, but did not disclose specific preclinical programs.

"If we can activate the expression of tumor suppressors, we could have an oncology therapeutic," said Maraganore. He also suggested using RNAa to reactivate the expression of hemoglobin- $\gamma$, an embryonic form of hemoglobin, to treat SCD.

Maraganore told SciBX that the competing invention claims from the three academic labs made it necessary for the company to license technology from each one to secure exclusive rights to RNAa.
"We've been following this field for a while," he said. "We built a roadmap of the key scientific papers and patent applications. The roadmap showed us that there were eight patents that covered everything. The patent office will ultimately decide which of the pending patents have the needed enablement and overcome prior art."

In any case, Alnylam thinks it has covered all the bases. "Our view is that one of these will shake out and we'll have the field sown up," said Maraganore.

\section{REFERENCES}

1. Schwartz, J.C. et al. Nat. Struct. Mol. Biol. published online July 6 , 2008; doi:10.1038/nsmb.1444

Contact: Bethany A. Janowski, University of Texas Southwestern Medical Center, Dallas, Texas

e-mail: bethany.janowski@utsouthwestern.edu

Contact: David R. Corey, same affiliation as above e-mail: david.corey@utsouthwestern.edu

2. Janowski, B.A. et al. Nat. Chem. Biol. 3, 166-173 (2007)

3. Fulmer, T. SciBX 1(12), 5-7; April 17, 2008

4. Chen, Z. et al. Mol. Cancer Ther. 7, 698-703 (2008)

\section{COMPANIES AND INSTITUTIONS MENTIONED}

Alnylam Pharmaceuticals Inc. (NASDAQ:ALNY), Cambridge, Mass.

Atlas Venture, Waltham, Mass.

Isis Pharmaceuticals Inc. (NASDAQ:ISIS), Carlsbad, Calif. miRagen Therapeutics Inc., Boulder, Colo.

Regulus Therapeutics LLC, Carlsbad, Calif. Salk Institute for Biological Studies, La Jolla, Calif. Sangamo BioSciences Inc. (NASDAQ:SGMO), Richmond, Calif. University of California, San Francisco, San Francisco, Calif. University of Texas Southwestern Medical Center, Dallas, Texas 